DOI: https://doi.org/10.47405/mjssh.v6i7.843

\begin{tabular}{|c|c|}
\hline$\sqrt{10}$ & Malaysian Journal of Social Sciences and Humanities (MJSSH) \\
\hline $\begin{array}{l}\text { Malaysian Journal of } \\
\text { socai sciences and }\end{array}$ & Volume 6, Issue 7, July 2021 \\
\hline (MJ-ssH) & e-ISSN : 2504-8562 \\
\hline & $\begin{array}{l}\text { Journal home page: } \\
\text { www.msocialsciences.com }\end{array}$ \\
\hline
\end{tabular}

\title{
A Study on Politeknik Tuanku Sultanah Bahiyah Students' Preparedness Towards Blended Learning in Communicative English
}

\author{
K. Navin Kumaran' ${ }^{1}$, Nor Salwa Binti Sulaiman' ${ }^{1}$ \\ ${ }^{1}$ General Studies Department, Politeknik Tuanku Sultanah Bahiyah, \\ 09000 Kulim, Kedah, Malaysia \\ Correspondence: K. Navin Kumaran (navin1206@gmail.com)
}

\begin{abstract}
Teaching and learning process heading to different dimension after the rising of technology. Even Malaysian Education Ministry is encouraging educators to practice different teaching process. Since the introduction of the Outcome-Based syllabus at Malaysian polytechnics, students are exposed to new ways of learning. This study purposes to investigate the suitability of the blended learning approach in learning the English language among diploma students of Politeknik Tuanku Sultanah Bahiyah. This learning approach is combination of online learning and traditional methods. In Malaysian polytechnics, online learning is made possible through the Curriculum Information Document Online System (CIDOS). For this study, a total of 80 students were selected from Civil Engineering Department. The responses of the students were elicited through a questionnaire survey. The results were then analyzed descriptively using the statistical software, SPPS version 22 . The results of the study indicated that there was a moderate level in students' preparedness in blended learning of communicative English. Recommendations were provided for future research.
\end{abstract}

Keywords: blended learning, online learning, CIDOS

\section{Introduction}

The introduction of the Outcome-Based Education (OBE) in the polytechnic curriculum opens the door to new possibilities in teaching and learning. Polytechnic lecturers are encouraged to diversify their teaching approaches to cater to the academic needs of students of various proficiency levels. Students are also exposed to new learning approaches. One of these learning approaches is blended learning.

Blended learning is defined as a combination of face to face learning and online learning (Kim, Bonk $\&$ Oh, 2008). In other words, students attend lessons in the classroom based on the set contact hours and the remaining learning period by online learning. The blended learning approach is implemented through the polytechnic's content learning management system which is known as Curriculum Information Document Online System (CIDOS). Students are encouraged to utilize the online resources available in CIDOS to enhance their academic learning. However, there are many questions remained to be answered. Students are used to the traditional classroom setting of learning. So are polytechnic students ready for online learning? Are they ready to be independent learners? Are the online resources found in CIDOS up to students' expectations? Are the learning contents interesting and challenging to students? To answer some of these questions, research questions were formulated to guide the objectives of this study. 


\section{Statement of the Problem}

The infusion of technology across the learning process is practised at all levels of teaching and learning in schools as well as in institutions of higher learning includes polytechnics. However, it appears that some students are not aware of this and portrayed some of their negative attitudes. Even though a number of students show positive side in blending technology in learning process, but still some students prefer old-fashioned learning process.

\section{Research Questions}

i. What are the perceptions of students towards the CIDOS system?

ii. What are the perceptions of students towards the online resources in CIDOS?

iii. What is the level of students' preparedness for blended learning by using CIDOS?

\section{Research Objectives}

i. To determine the perceptions of students towards the CIDOS system.

ii. To determine the perceptions of students towards the online resources in CIDOS.

iii. To determine the level of students' preparedness for blended learning by using CIDOS.

\section{Literature Review}

In the Malaysian education system, it is a general knowledge that the education system is too exam oriented. Critics argued that Malaysian students are not taught to be an independent learner. Instead, the teacher is looked upon as the sole authority of information. In the $21^{\text {st }}$ century, the education curriculum in Malaysia is beginning to change to accommodate new teaching and learning methods as well as incorporating new technologies in the syllabus. Among the new technologies is the internet.

The internet brings different possibilities in learning. It enables the students to obtain information anytime and anywhere beyond the normal classroom learning period. This brings to a various type of learning which is online learning or e-learning. According to Lim, Hong and Tan (2008), e-learning may include web-based courses, computer-mediated communications and multimedia enhanced delivery tools. Malaysian institutions of higher learning such as Open University of Malaysia and International Islamic University of Malaysia are implementing the online mode and blended mode respectively in their curriculum framework.

On the other hand, students still need some form of guidance from their teachers in their learning experiences. This is where the blended learning approach may be considered in the teaching and learning process.

There are a few definitions of blended learning. According to Singh (2003) as stated in Farahiza (2013), blended learning may be defined as the combination of multiple delivery media designed to complement each other and promote learning and application learned behavior. Whitelock and Jefts (2014) defined blended learning as a combination of traditional learning with web-based online approaches. Rubenstein (2013) and Watson (2008) as stated in Wong et al. (2019) mentioned that the learning content of blended learning can be delivered using a variety of methods such as face-to-face interactions, self-paced, individualized learning and online interactions.

According to Farahiza (2013), there are several benefits of blended learning such as enhanced social interaction, communication and collaboration. Learners and their instructor are able to share knowledge and learning ideas, build rapport and a sense of belonging in an online community. Students can collaborate with each other to complete their tasks online. Blended learning offers flexibility and efficiency. For example, learners who are unable to attend the physical classroom may attend a lesson 
via video or teleconference. Internet applications such as e-library, e-book, e-resources and others provide students with greater means to study at their own pace and access wide amount of learning materials through the internet. According to Silong and Ibrahim (2002), a well-developed online learning task may increase interactivity among students and further development of students' cognitive skills.

Although blended learning encourages students to be self-directed learners, there are some concerns on its implementation in the teaching and learning process. In a study conducted by Tham and Tham (2011) on the impact of blended learning in Asian countries, they discovered that certain challenges were preventing Asian higher educational institutes from harnessing the full potential of blended learning in higher education. For example, in China the education system is still exam-driven and teacher-centred. While there is some effort to introduce e-learning in the curriculum, the response has been described as lukewarm. In short, the mind set has to change in order to embrace new technologies that accompany the teaching and learning process.

A critical component of blended learning that helps to deliver online resources effectively is a learning management system. According to Petrovic and Kennedy (2015) as stated in Ajide and Chan (2019) defined a learning management systems (LMSs) as a collection of online software applications, packaged together to deliver teaching and learning in either a distance education or an on-campus mode. Petrovic and Kennedy added that LMSs are generally used for four purposes in an academic environment, namely resource or content provision, communication, assessment and administration.

In the Malaysian polytechnic education system, the learning management system is known as Curriculum Information Document Online System (CIDOS). The system was introduced in 2009 to implement the e-learning and blended learning concepts. According to the system's manual, "Curriculum Information Document Online System (CIDOS) is a web-based solution designed specifically for efficient and effective control over curriculum document inventory, $P \& P$ materials, and knowledge sharing".

Not much research has been done on the effectiveness of blended learning using CIDOS at the polytechnic education level. A study related to CIDOS was carried out by Nafisah, Aniza and Mohamad Hafiz (2016) of Politeknik Sultan Azlan Shah. One of the objectives of their study was to determine students' perceptions towards the usefulness of the online learning system namely CIDOS. Their study revealed that the perceptions of students on the usefulness of CIDOS as highly positive especially in taking quizzes and tests online.

In conclusion, blended learning has its benefits in enhancing the learning experiences of students by combining the best features of classroom learning and online learning applications. On the other hand, effective implementation of blended learning needs to take into account the suitability of learning contents and the right pedagogical approach.

\section{Methodology}

This study used the design of a type of survey, which is through a quantitative approach. Questionnaires were distributed to the study sample face to face.

\section{Respondents}

This study investigates a group of students from their respective department and were tasked to answer structured questions to elicit their responses. The participants for this study were 80 semester four students from the Civil Engineering Department. In semester four, the students took the DUE50032 Communicative English course. The convenient sampling method was used in the study as the students were readily available from the researchers' English classes. 


\section{Instrument}

The instrument for this study will include a self-constructed questionnaire with a four Likert scale. The questionnaire contained 20 question items that would elicit students' responses towards their perceptions on the CIDOS system, the online resources in CIDOS and students' level of preparedness for blended learning using CIDOS.

In implementing this study, students attended their normal learning periods in the classroom. They would then access CIDOS during their Student Learning Time (SLT). SLT refers to the student's independent study period outside of the classroom. Students would be grouped at a session where the researchers will explain the objectives of the study and the procedures on how the students would be able to answer the questionnaire.

\section{Data Analysis}

The data from the questionnaire was analysed using the SPSS statistical software (version 22) to determine the mean scores and the significant of the students' responses. The results were tabulated to enable the researchers to determine the students' overall level of preparedness towards blended learning and to prepare the required recommendations for the study.

\section{Findings and Discussion}

\section{What are the perceptions of students towards the CIDOS system?}

To answer the first research question, question items 1 to 7 were analyzed. Based on Table 1, for item 1 (mean 2.93), many students found that CIDOS is user friendly in terms of navigation and layout of content. However, for item 4 (mean 2.90), many students found that they have difficulty to access CIDOS using WIFI at polytechnic. For item 6 (mean 2.96), many students also found that the connection time to CIDOS is very slow.

However, in item 5 (mean 2.73) a considerable number of students found that they can use their broadband to access CIDOS anytime. Farahiza (2013) mentioned in her study that one of the weaknesses of online delivery learning is slow and limited access to the Internet. With regards to CIDOS, the bandwidth of the local area network ought to be upgraded to enhance the teaching and learning process. Furthermore, in item 7 (mean 3.00) many students are motivated to use CIDOS if they can gain access to it quickly.

Table 1: Students' responses towards their perceptions on the CIDOS system

\begin{tabular}{llcc}
\hline No & Item & Mean & $\begin{array}{l}\text { Std. } \\
\text { Deviation }\end{array}$ \\
\hline 1 & I find that CIDOS is user friendly in terms of navigation and layout of & & \\
& content. & 2.93 & .739 \\
2 & I can access CIDOS anytime. & 2.63 & .889 \\
3 & I can access CIDOS anywhere. & 2.46 & .681 \\
4 & I have difficulty to access CIDOS using WIFI at polytechnic. & 2.90 & 1.061 \\
5 & I can use my broadband to access CIDOS anytime. & 2.73 & .868 \\
6 & I find that the connection time to CIDOS is very slow. & 2.96 & .808 \\
7 & I am motivated to use CIDOS if I can gain access to it quickly. & 3.00 & .742 \\
8 & CIDOS supports my learning in the classroom. & 2.63 & .850 \\
9 & I find that the learning materials posted in CIDOS are useful. & 2.93 & .520 \\
10 & I believe that more online self-assessment will be useful to help me & & \\
& understand a learning topic better. & 2.73 & .639 \\
11 & I can interact with my lecturers and classmates using the online forum. & 2.36 & .668 \\
12 & I find that the online forum is not up to my expectation in increasing my & & \\
\hline
\end{tabular}




\begin{tabular}{|c|c|c|c|}
\hline & understanding of the topic learned. & 2.53 & .507 \\
\hline 13 & I can easily download the learning notes and assignments from CIDOS. & 3.10 & .758 \\
\hline 14 & I find it difficult to upload and sent my assignment using CIDOS. & 2.63 & 1.033 \\
\hline 15 & $\begin{array}{l}\text { I find it more convenient to send my assignments in hardcopy rather } \\
\text { than send a softcopy using CIDOS. }\end{array}$ & 2.80 & .846 \\
\hline 16 & I am ready to learn using CIDOS anytime and anywhere. & 2.93 & .739 \\
\hline 17 & $\begin{array}{l}\text { I am ready to learn using CIDOS to support my learning in the } \\
\text { classroom. }\end{array}$ & 2.90 & .661 \\
\hline 18 & $\begin{array}{l}\text { I believe that I will be more motivated in using CIDOS if I can access } \\
\text { the learning materials more quickly. }\end{array}$ & 2.96 & .764 \\
\hline 19 & $\begin{array}{l}\text { I am ready to learn using CIDOS if the overall system is up to my } \\
\text { expectations. }\end{array}$ & 2.86 & 628 \\
\hline 20 & Overall, I am satisfied with the online resources found in CIDOS. & 2.66 & .606 \\
\hline
\end{tabular}

\section{What are the perceptions of students towards the online resources in CIDOS?}

To answer the second research question, question items 8 to 15 were analyzed. Based on Table 1 , for item 9 (mean 2.93), students found that the learning materials posted in CIDOS are useful. For item 11(mean 2.36), many students disagreed that they can interact with their lecturers and classmates using the online forum. This view is supported by item 12 (mean 2.53), where a considerable number of students found that the online forum is not up to their expectation in increasing their understanding of the topic learned. In a study conducted by Menkhoff et al. (2017) on a blended learning module, students felt that two-way interaction was lacking between students and teaching staff. On the other hand, for item 13 (mean 3.10), many students can easily download the learning notes and assignments from CIDOS.

\section{What is the level of students' preparedness for blended learning by using CIDOS?}

To answer the third research question, question item 16 to 20 were analysed. Then, the average mean score of all items were obtained to determine the level of students' preparedness for blended learning. Based on Table 1, for item 16 (mean 2.93), many respondents mentioned they were ready to learn using CIDOS anytime and anywhere. For item 17 (mean 2.90), a reasonable number of respondents mentioned that they were ready to learn using CIDOS to support their learning in the classroom.

For item 18 (mean 2.96), many respondents believe that they would be more motivated in using CIDOS if they could access the learning materials more quickly. For item 19 (mean 2.86), a reasonable number of respondents were ready to learn online using CIDOS if the overall system is up to their expectations. For items 20 (mean 2.66), a moderate number of respondents mention they were overall satisfied with the online resources found in CIDOS.

Based on Table 2, the average mean score of all items (item 16-20) were obtained. The mean score is then tabulated again to determine the level of students' preparedness for blended learning as shown below:

Table 2: Average mean of question items

\begin{tabular}{lll}
\hline No & Item & Mean \\
\hline 16 & $\begin{array}{l}\text { I am ready to learn using CIDOS anytime and anywhere. } \\
17\end{array}$ & $\begin{array}{l}\text { I am ready to learn using CIDOS to support my learning } \\
\text { in the classroom. }\end{array}$ \\
18 & $\begin{array}{l}\text { I believe that I will be more motivated in using CIDOS if } \\
\text { I can access the learning materials more quickly. }\end{array}$ & 2.93 \\
19 & $\begin{array}{l}\text { I am ready to learn using CIDOS if the overall system is } \\
\text { up to my expectations. }\end{array}$ & 2.96 \\
20 & Overall, I am satisfied with the online resources found in CIDOS. & 2.86 \\
\hline
\end{tabular}


Based on the average mean score obtained in Table 2, the score of 2.86 falls under the moderate level as shown in Table 3. This indicates that the level of students' preparedness for blended learning is moderate.

Table 3: Level of preparedness

\begin{tabular}{cc}
\hline Mean Score & Level \\
\hline $1.00-2.00$ & Low \\
$2.01-3.00$ & Moderate \\
$3.01-4.00$ & High \\
\hline
\end{tabular}

\section{Conclusion and Recommendation}

The results of the study indicated that many students were in favour of the blended learning approach in learning the English language provided they could access the online resources more conveniently. The implementers of the CIDOS system ought to take this into account, namely speedier access to the online resources found in CIDOS. The online learning contents can also be improved further to meet students' learning needs.

The results of this pilot study could be used as initial feedback for a more comprehensive research in blended learning at the polytechnic education level. It is recommended that future research studies could focus on the following areas:

i. The design framework of the learning management system such as CIDOS in the implementation of blended learning.

ii. The suitability of online resources for blended learning.

iii. The suitability of teaching approaches, methods and techniques for blended learning.

iv. Effective ICT training for educators and learners in the implementation of blended learning.

\section{References}

Ajide, O. E., \& Chan, C. T. (2019). A study on the effectiveness of blended learning. Proceedings of the 2nd International Conference on Innovation and Technopreneurship (ICIT 2019) INTI University College, Malaysia. Retrieved on $24^{\text {th }}$ December 2019, from

https://my.laureate.net/Faculty/docs/Faculty\%20Documents/INTI\%20Conferences/Parallel\%20Session s\%204/4C/4C-06-P176\%20(Malaysia).pdf

Farahiza Zaihan Azizan. (2013). Blended learning in higher education institution in Malaysia. Proceedings of Regional Conference on Knowledge Integration in ICT 2013. Malaysia. $\begin{array}{lllll}\text { Retrieved } \quad \text { 17th } & \text { January, } & \text { from }\end{array}$ http://library.oum.edu.my/oumlib/sites/default/files/file_attachments/odlresources/4334/blended-learning.pdf

Kim, K.-J., Bonk, C. J., \& Oh, E. J. (2008). The present and future state of blended e-learning in workplace learning settings in the United States. Performance Improvement, 47(8), 5-16. USA.

Lim, C. Y. B., Hong, K. S., \& Tan, K. W. (2008). Acceptance of e-learning among distance learners: A Malaysian perspective. Proceedings Ascilite Melbourne 2008. Melbourne.

Menkhoff T., Thang T. Y. and Wong Y. K. (2017). Evaluating the blending of an e-learning module into a knowledge management course: A Case Study from The Singapore Management University (SMU), September 2017. Singapore.

Nafisah, H., Aniza, T., \& Mohamad, H. A. R. (2016). Kajian persepsi pelajar semester satu terhadap pembelajaran secara atas talian. Politeknik Sultan Azlan Shah. Malaysia. Retrieved on 30th January, 2017, from http://www.psas.edu.my/v7/index.php/muat-turun/psas-digest-2017

Petrovic, T. and Kennedy, G. (2015). How often do students use a learning management system in an on-campus, problem-based learning curriculum? ascilite. Australia. Retrieved on 10th February, 
2016 ,

http://www.ascilite.org.au/conferences/brisbane05/blogs/proceedings/61 Petrovic.pdf

from

Rubenstein, H. (2013). Recognizing e-learning's potential \& pitfalls. Learning \& Training Innovations, 4(4), 38. USA.

Silong, A.D., \& Ibrahim, D.Z. (2002). Students' perspectives on effective online teaching and learning. In D. Murphy, S. Namin, \& Y. Z. Wei (Eds.), Advancing online learning in Asia (pp. 15-19). Hong Kong: Open University of Hong Kong Press.

Singh, H. (2003). Building effective blended learning program. Educational Technology, 43(6), pp 5154.

Tham, K.O., \& Tham, C.K. (2011). Blended learning - A focus study on Asia. International Journal of Computer Science Issues, 8(2).

Watson, J. (2008). Blending learning: The convergence of online and face-to-face education. International Association for K-12 Online Learning (iNACOL).

Whitelock, D \& Jefts, A. (2014). Editorial: Journal of Education Media special issue on Blended Learning. Journal of Educational Media, 28(2-3), 99-100.

Wong, F. F., Thang, S. M., Noorizah, M. N., Hafizah, L., \& Mohd. S. A. A. (2019). A blended approach in teaching an EAP course: Malaysian instructors' perceptions of the new course materials. Universiti Kebangsaan Malaysia. Retrieved on 30th January, 2020, from http://ejournals.ukm.my/31/article/view/1113/1005 